\title{
Norges skjulte nasjonallitteratur
}

\author{
Det skjuler seg store litterære skatter i de mange hyllemeter som finnes av arkiv over eldre \\ medisinske journaler. En ny og mer allsidig forfattervirksomhet er siden kommet til gjennom \\ de elektroniske journalene, som baseres på tastaturakrobatikk og talegjenkjenning. Begge \\ hører allerede til vår litterære arv.
}

At vanlig skjønnlitteratur blir lest, forutsetter at den er tilgjengelig. På grunn av hard konkurranse innen forlagssektoren kreves det imidlertid en betydelig markedsføring for å nå frem til leserne. Hvert år kasseres det millionvis av bøker som ble utgitt året før, og som ingen brydde seg om å kjøpe og lese. Likevel er dette fenomenet bare en liten del av virkeligheten. Mye god litteratur er skjult. Noe skyldes at den bare foreligger som manuskript. Dessuten er en del av vår litterære arv hemmelig, og det skal den også forbli. I 1981 skrev jeg en liten artikkel i Nordisk Medicin for å gjøre oppmerksom på de mange litterære kvaliteter som finnes i våre arkiverte medisinske journaler, og i en bok om medisinske anekdoter fra 1986 ble et helt kapittel viet dette emnet (1). Begge steder var teksten ledsaget av rikelig med originale sitater for å gi noen smakebiter, og her kommer originalartikkelen på ny.

Gamle journaler er lite tilgjengelige både for helsearbeidere og pasienter. De må først bestilles fra arkivet, og dernest må man vente lenge $f \varnothing r$ de kommer. Siden er det en enorm jobb å lese gjennom skribleriene fra de mange legene, skrevet på alle mulige og umulige tidspunkter og til dels under dramatiske forhold. Nye journaler er helt eller delvis elektroniske, og da er situasjonen enda verre. Informasjonsmengden er blitt ufattelig mye større, antall variabler og tilheftede dokument har økt eksponentielt, og som resultat må en «skrolle» over dataskjermen i utrolig lang tid (2). Men så kan man også få rikelig lønn for strevet. Det omfatter ikke bare små litterære perler, men også helt nye ord og uttrykk som oppstår når journalen baseres på systemer for talegjenkjenning. Saken dreier seg om alt fra det legen vitterlig har sagt, til det som datamaskinen tolker av legens ulyder og dypfølte sukk innimellom lange sekvenser der lydrommet fylles med æææææææ....
Iblant kan det komme store overraskelser, for det elektroniske talegjenkjenningssystemet lever sitt eget liv. For ikke lenge siden skulle en kvinne legges inn på sykehus med en lidelse i urinblæren, og hun ble tatt imot av en yngre lege ved navn Bekkelund. Neste dag kunne man lese på skjermen at hun var blitt undersøkt av dr. Bekkenbunn. Slikt beriker den medisinske hverdagen.

For øvrig omfatter den offentlig tilgjengelige «journallitteraturen» for en stor del korte og fyndige sitat, slik det har stått eksempler på i Tidsskriftets humorspalte og i samlinger av journalsitater som kommer på folkemunne i helsevesenet (3-5). For de lengre og mer episke eller lyriske fremstillingene inviterer jeg både pasienten, forlagsredaktøren og litteraturanmelderen til å gå i arkivet og virkelig studere. Men pass på taushetsplikten!

\section{Ole Didrik Lærum \\ ole.laerum@gades.uib.no}

Ole Didrik Lærum (f. 1940) er professor (adj.) ved Københavns Universitet og professor emeritus ved Universitetet i Bergen

\section{Litteratur}

1. Lærum OD. Fra blodigler til datamaskin: muntre legehistorier: utgitt i forbindelse med Den norske lægeforenings 100-års-jubileum. Oslo: HjemmetFagpresseforlaget, 1986: 49-56.

2. Lærum H. IKT i sykehus: tveegget teknologi. Overlegen 2011; nr. 3: 8-9 http://legeforeningen.no/yf/overlegeforeningen/Om-oss/Overlegen/ overlegen-3-2011/ (2.6.2012).

3. Lederballe O, Krag N. Journalinnsyn - så klart. Oslo: Ad Notam Gyldendal, 1994. 4. Oksvold MP. Gullkorn fra pasientjournalen. Oslo: Gyldendal, 2008.

\section{Har pasientjournalen litterar verdi?}

Ole Didrik Lærum, professor, dr med, Gades Institutt, Avdeling for Patologi, N-5916 Haukeland Sykehus, Bergen. Nordisk Medicin 96: 293-294,1981.

Virkeligheten overgår enhver diktning, og diktningen har verdi i den grad den gjenspeiler det virkelige liv. Dette gjelder den litteratur som kommer på trykk. Men hva med det enorme antall livsskjebner og menneskelige beretninger som ligger gjemt i våre pasientjournaler?
Journalopptaket og den kliniske undersøkelsen er pasientens første møte med legen når han kommer inn på sjukehuset. Det blir ofte en fortrolig atmosfære og god menneskelig kontakt. Pasienten vil gjerne berette om hva som har skjedd, og legen er interessert i å se hva som foreligger. Ofte er det en yngre lege, kanskje en student. I enerom synes pasienten det er lettere å snakke med legen og så kommer livshistorien fram.

Likevel er det ikke alltid så lett å få noe ut av pasienten, og det kan ha mange årsaker. Enkelte ting kan være vanskelige å spørre 